\title{
Correspondence
}

The Editor,

Journal of Glaciology

SIR,

\section{Estimate of ice-surface velocity over a 4 year period on Glaciar Arenales, Hielo Palagónico .Norte, Chile}

Climate change in the southern Andes has been marked by a loss of approximately $100 \mathrm{~m}$ of ice-surface thickness from the $3200 \mathrm{~km}^{2}$ Hielo Patagónico Norte (HPN; northern Patagonia ice field) over the last 120 years (Winchester and Harrison, 1996). Because of the remoteness and inaccessibility of the ice field, centring on $47^{\circ} 00^{\prime} \mathrm{S}, 73^{\circ} 30^{\prime} \mathrm{W}$, much of the work investigating change has focused on the movements of glacier ice fronts. Ice-front positions have been extrapolated from aerial photographs (Aniya, 1985, 1987, 1992; Wada and Aniya, 1995), scant historical sources, dendrochronology and lichenometry (Winchester and Harrison, 1996). Ice-surface velocity has been directly measured for only two of the 30 or so glaciers that descend from the ice field, Glaciares San Rafael and Soler (Fig. 1).

This note records an indirect estimate of a mid-valley ice-surface velocity on Glaciar Arenales obtained from aerial photographs taken in 1975 and 1979. In February 1996 we investigated Glaciares Colonia, Arco and Arenales on the southeastern side of the ice field. All three glaciers begin their descents from the ice field over icefalls; Glaciar Arenales then flows eastwards for around $8 \mathrm{~km}$ before joining Glaciar Colonia coming in from the northwest. Our velocity estimate was based on the distance travelled over a 4 year period by a mass-movement feature near the Arenales valley midpoint (Fig. 2). The 1:50000 regional map (Lago Colonia 4715-7300, No. 381) drawn from the 1975 aerial photograph (see Fig. 2) shows a comma-shaped feature (at $47^{\circ} 15^{\prime} \mathrm{S}, 73^{\circ} 18^{\prime} 30^{\prime \prime} \mathrm{W}$ ) some $750 \mathrm{~m}$ long and $150 \mathrm{~m}$ wide extending out from the southern valley wall to approximately one-third of the way across the Arenales surface and about $3.5 \mathrm{~km}$ above the Colonia junction. This feature, which we identified on the ground as a large rock-fall/ debris-flow complex (Fig. 3), with the comma form created by the differential flow rates of surface ice, also appears on the 1979 photograph. Measurement of the distance covered by the tip of the feature between the two dates provides an approximate rate of surface movement over the 4 year period of $150 \mathrm{~m} \mathrm{year}^{-1}$ or $0.41 \mathrm{~m} \mathrm{~d}^{-1}$.

\section{PREVIOUS SURVEYS}

The ice-surface velocity of Glaciar San Rafael has been measured on three different occasions (Naruse, 1985; Harrison and Winchester, 1992; Rignot and othes, 1996). All three surveys were in close agreement, showing ice-surface velocity near the terminus averaging $17-17.5 \mathrm{~m} \mathrm{~d}^{-1}$ over the 12 year period during which the studies took place. Although agreement over the ice-front movement rate is interesting per se, the velocity of this tidewater calving glacier is related partly to calving flux (Warren and others,

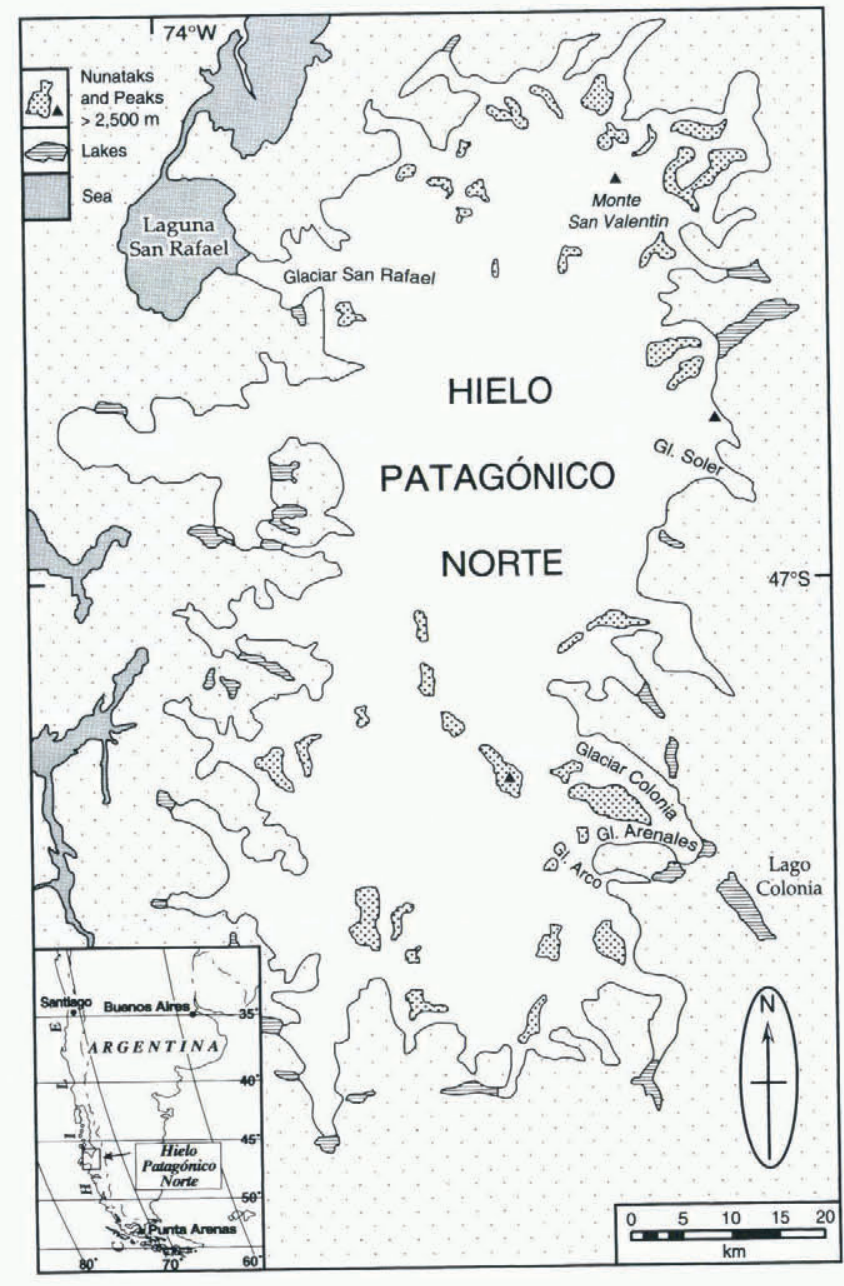

Fig. 1. Hielo Patagónico Norte and its glaciers.

1995), and thus is likely to be unrepresentative of the velocity of most of the other HPN outlet glaciers.

The other direct measurement of ice-surface velocity was carried out on the $8 \mathrm{~km}$ long valley section of the landbased Glaciar Soler on the eastern side of HPN in 1985 (Naruse, 1987; Naruse and others, 1992). The survey showed the glacier's surface moving with an average velocity, between 21 survey stations, of $0.41 \mathrm{~m} \mathrm{~d}^{-1}$. At around its valley midpoint the rate was $0.49 \mathrm{~m} \mathrm{~d}^{-1}$, with a rate of $0.39 \mathrm{~m} \mathrm{~d}^{1}$ at the point above this. An indirect approach to velocity measurement using aerial photographs was also applied to Glaciar Soler by Aniya and Naruse (1987) who, by dividing a number of annually formed ogive bands by the length of the glacier section containing them, derived an average icesurface velocity over a 32 year period of 170 mear $^{-1}$ $\left(0.47 \mathrm{~m} \mathrm{~d}^{-1}\right)$.

\section{DISCUSSION}

The extraordinary similarity in the surface velocities of Glaciares Soler and Arenales, averaging $0.39-0.49 \mathrm{md}^{-1}$ around their midpoints, is perhaps surprising considering their differences. The Soler, according to Naruse (1987), has an average slope angle of $2.9^{\circ}$ and width of $1.5 \mathrm{~km}$, compared with the average $1^{\circ}$ slope angle and $2 \mathrm{~km}$ width of the 


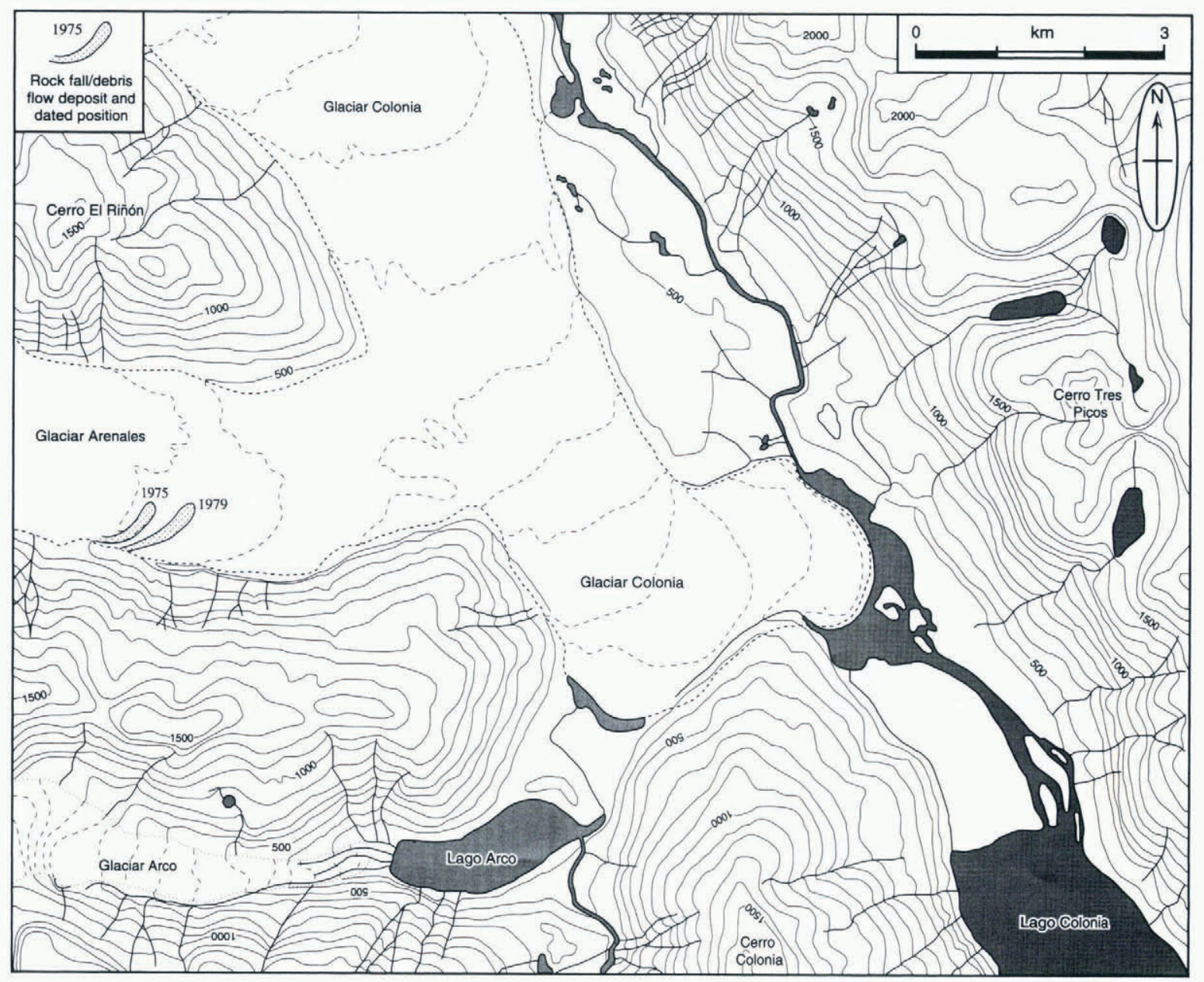

Fig. 2. The Arenales, Colonia and Arco glacier valleys showing the rock-fall/debris-flow complex in its 1975 and 1979 positions.

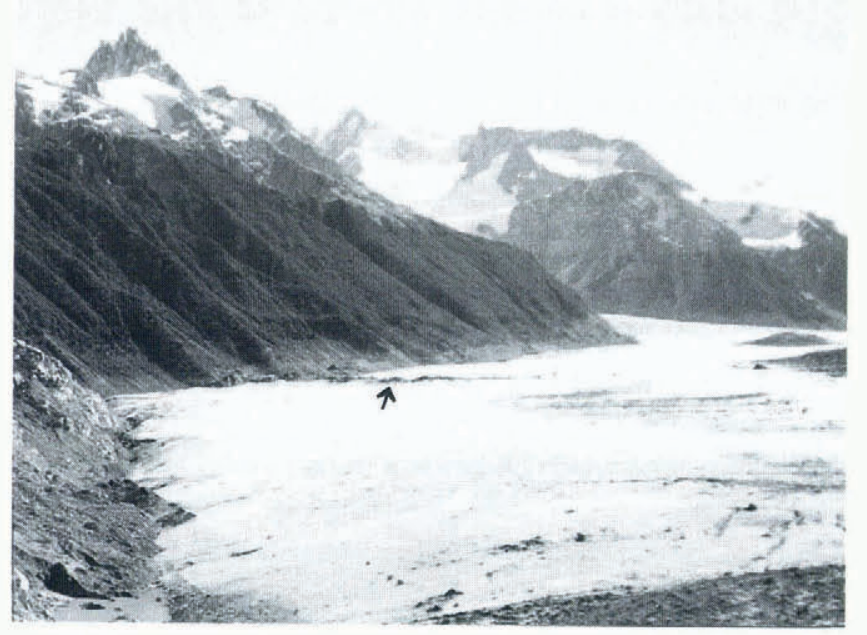

Fig. 3. A partial view of the southern flank of Glaciar Arenales, with the ellipse of debris material to be seen (arrowed) on its surface in the middle distance, about $3.5 \mathrm{~km}$ from the camera. (Photograph by V.W., fanuary 1996.)

Arenales which, after joining Glaciar Colonia, flows to a joint terminus $3.5 \mathrm{~km}$ further downslope. Although it is difficult to be very precise when using aerial photographs without specialist equipment, the approximate accuracy of our indirect approach to measurement of ice-surface velocity is supported by the degree of correspondence between the indirect and direct values obtained by Aniya and Naruse
(1987) and Naruse (1987) over long and short time periods, respectively.

\section{ACKNOWLEDGEMENTS}

We thank The Linnean Society of London and the University of Coventry for funding, and Raleigh International for providing full logistical back-up and obtaining the necessary permission from CONAF (Corporación Nacional Forestal) for us to work in the San Rafael national park. Most of all we thank the teams of Raleigh "Venturers" who assisted us through thick and thin in the fieldwork.

School of Geography,

VANESSA WINCHESTER

University of $O x$ ford,

Mansfield Road,

Oxford OX137B, England

Centre for Quaternary Science,

STEPHAN HARRISON

School of Natural and Environmental Sciences,

Coventry University,

Priory Street,

Coventry CV15FB, England

24 February 1997

\section{REFERENCES}

Aniya, M. 1985. Aerial photographic surveys over Soler, Nef and San Rafael glaciers. In Nakajima, C., ed. Glaciological studies in Patagonia Northern Ice- 
field, 1983-1984. Nagova, Japanese Society of Snow and Ice. Data Center for Glacier Research, 88-93.

Aniva, M. 1987. Aerial surveys over the Patagonia icefields. Bull. Glacier Res. $4,157-161$.

Aniya, M. 1992. Glacier variation in the Northern Patagonia Icefield, Chile, between 1985/86 and 1990/91. Bull. Glacier Res. 10, 83-90.

Aniva, M. and R. Naruse. 1987. Structural and morphological characteristics of Soler glacier, Patagonia. Bull. Glacier Res. 4,69-77.

Harrison, S. and V. Winchester. 1992. The San Rafael glacier region in southern Chile: glacier recession, rates of ice movement and the development of ice-marginal debris flows. Middlesex University Geography and Planning Paper 26, 1 - 32.

Naruse, R. 1985. Flow of Soler glacier and San Rafael glacier. In Nakajima, C. ed. Glaciological studies in Patagonia Northern Icefield, 1983-1984. Nagoya, Japanese Society of Snow and Ice. Data Center for Glacier Research, 64-69.

Naruse, R. 1987. Characteristics of ice flow of Soler glacier, Patagonia. Bull. Glacier Res. 4, 79-85.

Naruse, R., H. Fukami and M. Aniya. 1992. Short-term variations in flow velocity of Glaciar Soler, Patagonia, Chile. J. Glaciol., 38(128), 152-156.

Rignot, E., R. Forster and B. Isacks. 1996. Interferometric radar observations of Glaciar San Rafael, Chile. 7. Glaciol., 42 141), 279-291.

Wada, Y. and M. Aniya. 1995. Glacier variations in the Northern Patagonia Icefield between 1990/91 and 1993/94. Bull. Glacier Res, 13, 111-119.

Warren, C. R., N. F. Glasser, S. Harrison, V. Winchester, A. R. Kerr and A. Rivera. 1995. Characteristics of tide-water calving at Glaciar San Rafael, Chile. 7. Glaciol., 41 (138, 273-289.

Winchester, V. and S. Harrison. 1996. Recent oscillations of the San Quintin and San Rafael glaciers, Patagonian Chile. Geogr. Ann., 78A(1), 35-49,

SIR,

\section{Reference overlooked in "Determination of timing and location of water movement and ice-layer formation by temperature measure- ments in sub-freezing snow" by Pfeffer and Humphrey}

In our recent paper (Pfeffer and Humphrey, 1996), we neglected to make reference to a very closely related previous paper (Echelmeyer and others, 1992). Since part of Echelmeyer and others' work is nearly identical to part of ours, we want to draw attention here to their work. Their temperature measurements and subsequent analysis led to inferences about refreezing and piping at depth which are compatible with our conclusions. Their work also shows evidence of pipes transporting water to greater depths than at our site (a more shallow snowpack overlying superimposed ice), and provides additional convincing evidence of the effectiveness of piping and layering processes in transporting water through sub-freezing snow.

\section{Institute of Arctic and Alpine Research \\ University of Colorado, CB-450, \\ Boulder, Colorado 80309-0450, U.S.A.}

\section{Department of Geology and Geophysics \\ University of Wyoming, Laramie, \\ Wyoming 82071, U.S.A.}

W.T. PfefFer

\section{March 1997}

\section{REFERENCES}

Echelmeyer, K., W. D. Harrison, T. S. Clarke and C. Benson. 1992. Surficial glaciology of Jakobshavns Isbra, West Greenland: Part II. Ablation, accumulation and temperature. 7. Glaciol., 38(128), $169-181$.

Pfeffer, W.T. and N. F. Humphrey. 1996. Determination of timing and location of water movement and ice-layer formation by temperature measurements in sub-freezing snow. J. Glaciol., 42 (141), 292-304.
SIR,

Comments on "Temperate ice permeability, stability of water veins and percolation of internal meltwater" by L. Lliboutry

This paper begins by saying: "According to Nye (1976), the outburst of glacier-dammed lakes, in particular the wellknown Icelandic jökulhlaups, should proceed from irreversible broadening of the capillary veins". The paper quoted, in fact, says exactly the opposite. Indeed, it has a complete section (section 6) explaining why vein flow should not lead to jökulhlaups. It is hard to see how such a fundamental misunderstanding could arise but I am glad to have this opportunity of correcting it.

A few lines further on there is a second point. Professor Lliboutry says "Nye's (1976) theory... contradicts Nye and Mae (1972)" but does not elaborate further. No contradiction was intended. If he could say what kind of contradiction he has in mind here, I could try to resolve it.

\section{H. H. Wills Physics Laboratory \\ University of Bristol, \\ Bristol BS8 1TL, England}

\section{February 1997}

\section{REFERENCES}

Lliboutry, L. 1996. Temperate ice permeability, stability of water veins and percolation of internal meltwater. F. Glaciol., 42 (141), 201-211.

Nye, J. F. 1976. Water flow in glaciers: jökulhlaups, tunnels and veins. J. Glaciol., 17 (76), 181-207.

Nye, J. F. and S. Mac. 1972. The effect of non-hydrostatic stress on intergranular water grains and lenses in ice. f. Glaciol., 11 (61), 81-101.

SIR,

Reply to the comments by f. Nye on "Temperate ice permeability, stability of water veins and percolation of internal meltwater" by

\section{Lliboutry}

Professor Nye is right and I apologize. I do not remember whether I intended to say "...Icelandic jökulhlaups might proceed ..." instead of "should proceed", or if my wrong assertion came from not reading again Nye's (1976) paper before writing my introduction. Anyway, my sentence should not refer to jökulhlaups and read: "According to Nye (1976), an irreversible broadening of the water veins can occur if the pressure difference between the ends of the vein is fixed."

The essential point is that Nye's stability analysis of water discharge through capillary veins was unsound, because capillary and salinity effects were ignored. Nye applied to veins Röthlisberger theory for large waterways. In this theory, melting at the walls comes only from the energy loss due to the water discharge. For capillary veins, this term, as well as the shrinking by plasticity, are totally negligible. The heat flux that reaches the walls is almost exclusively (with my notations)

$$
\phi=\frac{2 \pi K_{\mathrm{i}}}{\ln (D / d)}\left(\theta_{\mathrm{L}}-\theta_{\mathrm{V}}\right)
$$

where $\theta_{\mathrm{L}}$ and $\theta_{\mathrm{V}}$ are the temperatures within the ice at the lenses walls and at the veins walls, respectively. Both are 